\title{
Petrographic Characterization of the Semi-industrial Mine of the Sav'or-ci Company (Groudji, Djekanou Department, Center of Côte D'Ivoire)
}

\author{
Ouattara Bakary ${ }^{1, *}$, Coulibaly Inza ${ }^{2}$, Yao Kouakou Alphonse ${ }^{3}$, Ouattara Gbele ${ }^{3}$ \\ ${ }^{1}$ Polytechnic Doctoral Scholl, Polytechnic Institute Félix Houphouët-Boigny (INP-HB), Yamoussoukro, Côte d'Ivoire \\ ${ }^{2}$ UFR of Environmental Sciences and Management, Nangui Abrogoua University, Abidjan, Côte d'Ivoire \\ ${ }^{3}$ Department of Earth Sciences and Mineral Resources (STeRMi), National Polytechnic Institute Félix Houphouët-Boigny (INP-HB), \\ Yamoussoukro, Côte d'Ivoire
}

\section{Email address: \\ danvobekah@gmail.com (O. Bakary) \\ *Corresponding author}

\section{To cite this article:}

Ouattara Bakary, Coulibaly Inza, Yao Kouakou Alphonse, Ouattara Gbele. Petrographic Characterization of the Semi-industrial Mine of the Sav'or-ci Company (Groudji, Djekanou Department, Center of Côte D'Ivoire). Earth Sciences. Vol. 10, No. 1, 2021, pp. 27-35. doi: $10.11648 /$ j.earth.20211001.14

Received: February 15, 2021; Accepted: March 22, 2021; Published: March 30, 2021

\begin{abstract}
SAV'OR-CI's semi-industrial mine is located in Groudji, (Djékanou department), in the central-eastern part of Côte d'Ivoire, in the southern part of the Oumé-Fétékro birimian greenstone belt (West African craton). The Birimian terrains was affected by multiple deformation and mineralization events. This study is a contribution to resolve some issues in the Bririmian such as the improvement of petrography and knowledge. The methodology is on macroscopic to microscopic observations. The lithology of SAVO'R gold mine consists of four major units. The first unit, volcanic, made of volcanic lavas (metabasalt and rhyodacite) and volcaniclastics (mafic tuffs and felsic volcaniclastics). The second unit is a plutonic rocks which is summarized by metagranodiorites and granodiorites. The third unit which outcrops in the form of vein is represented by aplites and microgranites. The last unit is composed of metamorphic rock, precisely gneisses. The presence of lavas, and volcaniclastics reveal respectively that the effusive volcanism and the explosive volcanism have occurred during the setting of area rocks. All lithologies have been affected by hydrothermal alteration marked by quartz veins and veinlets, feldspars, carbonates, often associated with sericite, chlorite and sulphides. Gold is not visible to the eye in the observed lithologies. These rocks are affected by a metamorphism of greenschist facies marked by the presence of chlorite, sericite and epidote minerals.
\end{abstract}

Keywords: Ivory Coast, Petrography, Groudji, Birimien, Gold

\section{Introduction}

The Paleoproterozoic terrains (2.2-2.0 Ga on average) of West Africa (Birimian) are known to dominate the entire West African Craton [1, 2, 6, 24, 25, 28] (Figure 1). The Birimian terrains consist of greenstone belts and intracratonic basins more or less stretched in the NE-SW direction. These terrains contain plutono-volcanic, volcaniclastic and sedimentary rocks, globally metamorphosed under the conditions of greenschist facies to locally amphibolitic and intruded by granitoid massifs. These birimian formations are favourable for gold mineralization. In fact, in West Africa, gold was mainly localized within the Paleoproterozoic terrains $[19,20]$, i.e., in the Birimian and Tarkwaian formations. These Birimian terrains therefore constitute a particular target for mining and academic research. The mining research carried out over the last few decades has brought to light numerous deposits including the Angovia, Tongon, Bonikro, Ity, Agbaou, Dougbafla, Afema, Sissingué $[3,9,16,17,18,19,22,23]$, as well as promising prospects and semi-industrial mines such as SAV'OR-CI SARLU (Figure 2), Ciel Vincent, Ivoire Mining Ressource SARL, Nassa Gold SARL and Gold Koss Scoop. The understanding of the context in which these gold mineralizations are being 
developed in these Birimian terrains is therefore necessary. It is in this context that this study was initiated in order to: (i) characterize the different lithologies of the semi-industrial SAVOR mine of Groudji and; (ii) to better understand the
Eburnean orogenic event. All these to understand the setting up of these formations in order to contribute to the revival of thee Ivorian mining sector.

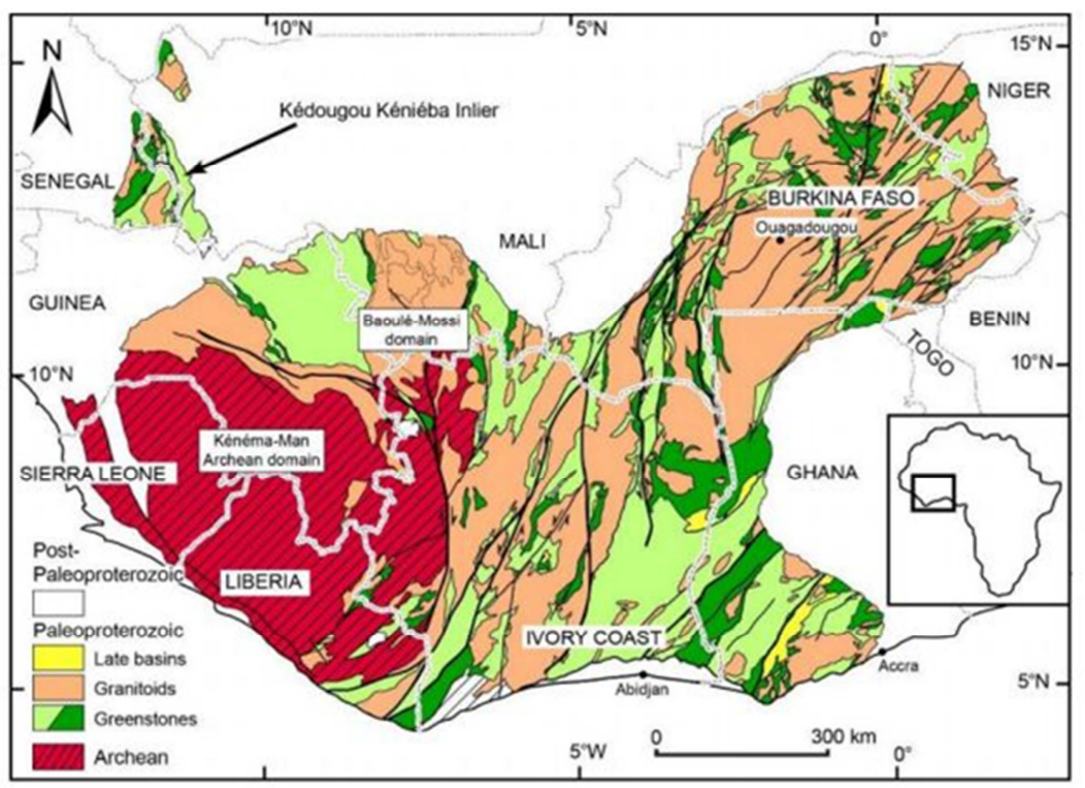

Figure 1. Simplified geological map of the West African craton (modified from [21]).

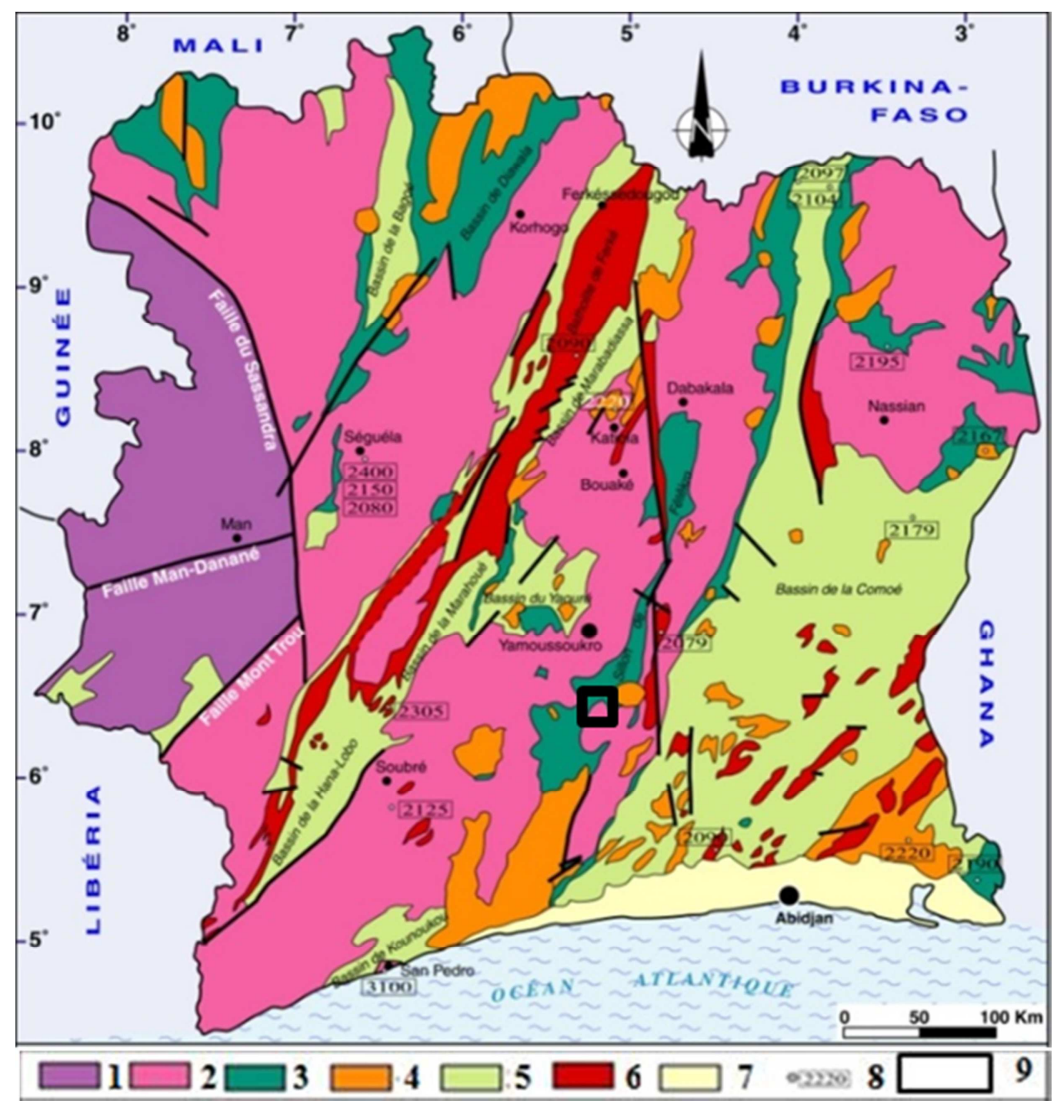

Figure 2. Simplified geological map of Ivory Map at 1/ 1000000 [26].

1- Archean domain. 2- Granitoids, banded granites, gneiss and undifferentiated migmatites (ages greater than 2.4 Ma). 3-Volcanism and volcano-sedimentary rocks undifferentiated. 4- calc-alkaline granitoids located in sedimentary basins. 5- sedimentary and volcano-sedimentary basins. 6- Ferké batholite: two-mica granitoids associated or not with meridian strike-slip structures 7- post-birimian formations; coastal sedimentary basins. 8- ages. 9- study area. 


\section{Geological Context}

Côte d'Ivoire belongs to the southern part of the West African Craton and more precisely to the Man or Leo Ridge (Figure 1). It consists of a Precambrian basement which represents $97.5 \%$ of its surface area and a secondary-tertiary coastal sedimentary basin covering $2.5 \%$ of the territory. This Precambrian basement comprises an Archean domain (Kenema-Man) to the west (3600-2500 Ma) and a Paleoproterozoic domain (Birimian) also called the BaouleMossi domain to the east (2500-1800 Ma), separated by the Sassandra fault ([5]; Figure 2). The semi-industrial mine SAV'OR, located in the department of Djékanou, belongs to the Baoulé-Mossi domain (Figure 2). The Birimian consisting of juvenile formations generated during a major crustal-episode between 2.2 and $2.1 \mathrm{Ga}$ ([2, 4, 6, 24, 27, 28]). Birimian rocks cover two thirds of Côte d'Ivoire and are materialized by alternating furrows and volcano-sedimentary basins generally oriented NS to NE and encased by areas of granito-gneiss. These different lithological units are intruded by granitoids of various nature, shape and size $([7,12,15$, 30]).

The geology of the Djékanou Department is composed of chlorite-schists, ampelites, metavolcanic rocks with brecciated facies, biotite granitic orthogneiss, biotite and/or hornblende granodiorite, and biotite and/or hornblende metagranodiorites ([11]; Figure 3).

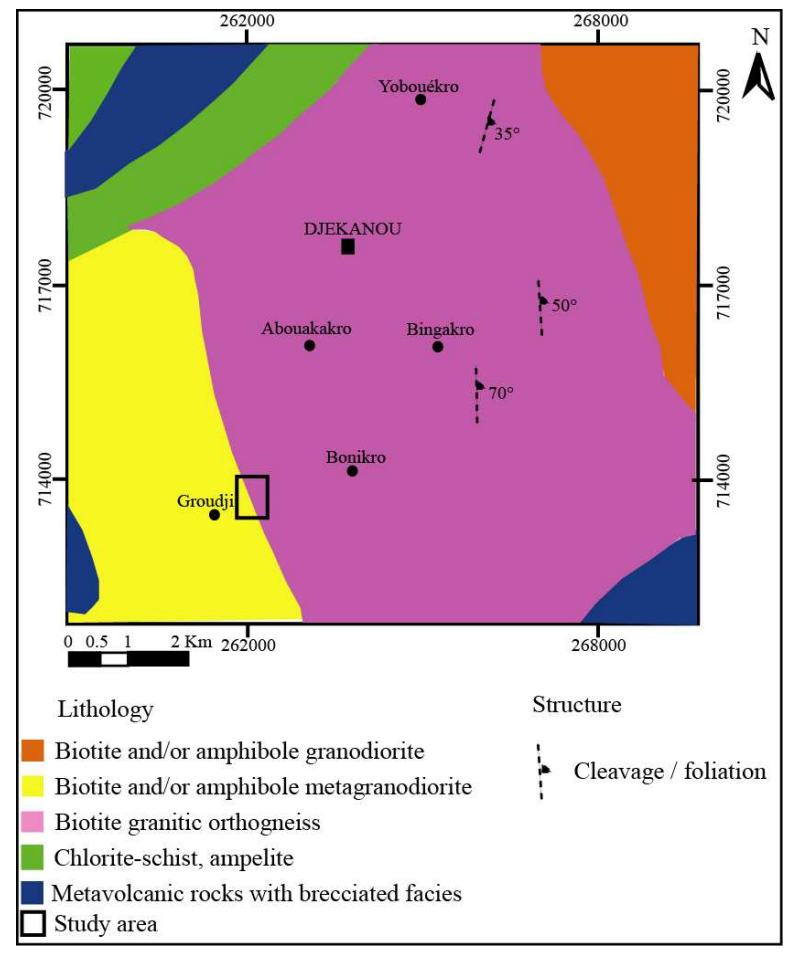

Figure 3. Geological map of the Djekanou Department ([11]).

\section{Methodology}

This stage will focus on petrographic description (macroscopic and microscospic). Representative samples of the different facies were selected for the laboratory phase in order to bring more precision to the macroscopic petrography. The preparation and the study of thin sections took place at the Ressources Minérales et Energétiques.

Geology, Mineral and Energy Resources Laboratory of the UFR of Earth Sciences and Mining Resources (UFR STRM) of the Félix Houphouët-Boigny University of AbidjanCocody.

\section{Results}

The lithologies of the study area consist of volcanic rocks (volcanic lava and volcaniclastics), semideep rocks (aplites and microgranites), granitoids (métagranodiorites and granodiorites, metasediments (chlorite-sericite-schists) and metamorphic rocks (gneiss). All of these lithologies are affected by a mineralized quartz vein oriented $\mathrm{N} 20^{\circ}$, sheared in its western part causing a dextral strike.

\subsection{Volcanic Rocks}

Volcanic rocks are represented by volcanic lavas (metabasalts, rhyodacites) and volcaniclastics (felsic and mafic volcaniclastics).

\subsubsection{Metabasalts}

The metabasalts are melanocratic and crossed cut by carbonate veins (Figure 4 A). With the naked eye, chloritization of the ferromagnesian minerals can be observed. Under the microscope, these rocks show a porphyritic microlitic texture with pyroxene phenocrystals (Figure 4 B). The latter are most often altered and transformed into amphiboles, chlorite and epidote. Mesostasis consists of carbonates, chlorite and epidote minerals. To this we must add quartz-carbonates veinlets. Sulphides and oxides are also observed.

\subsubsection{Rhyodacites}

The rhyodacites are leucocratic and Crossed cut by quartzfeldspars veins (Figure $4 \mathrm{C}$ ). At the naked eye we can observe an intense sericitization of these rocks. In thin sections, these rocks show a porphyritic microlithic texture (Figure $4 \mathrm{D}$ ). The phenocrystals observed are quartz and plagioclase. These plagioclase crystals are generally altered and transformed into sericite and epidote. Mesostasis consist of quartz-feldspars minerals associated with sericite, epidote and chlorite crystals. Quartz veinlets are often associated with plagioclase, chlorite and epidote crystals.

\subsubsection{Felsic Volcaniclastics}

These rocks are massive and consist of a quartz-feldspar matrix and felsic clasts (Figure $4 \mathrm{E}$ ). In thin sections, these rocks show a porphyritic microlitic texture (Figure $4 \mathrm{~F}$ ). Plagioclase occurs in phenocrystals generally altered and transformed into sericite and carbonates. Quartz also occurs as phenocrystals with remarkable rolling extinction. Mesostasis consists of quartz, carbonates and sericite. Clasts are felsic and generally consist of quartz and feldspars. There 
are also carbonates-quartz-sericite veinlets and some opaque
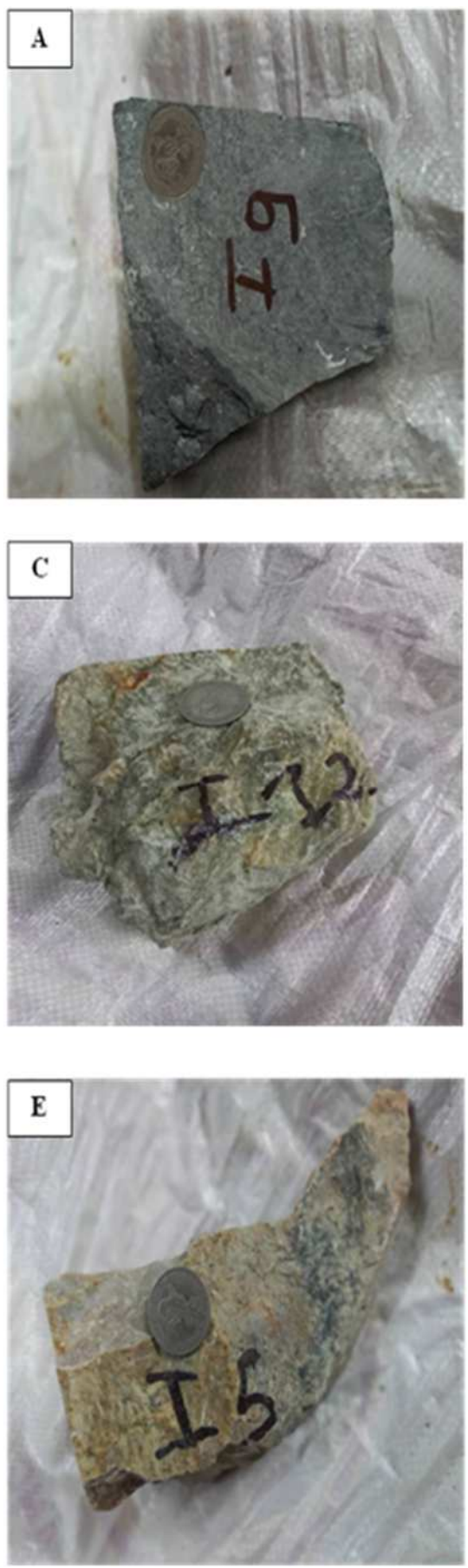

minerals.
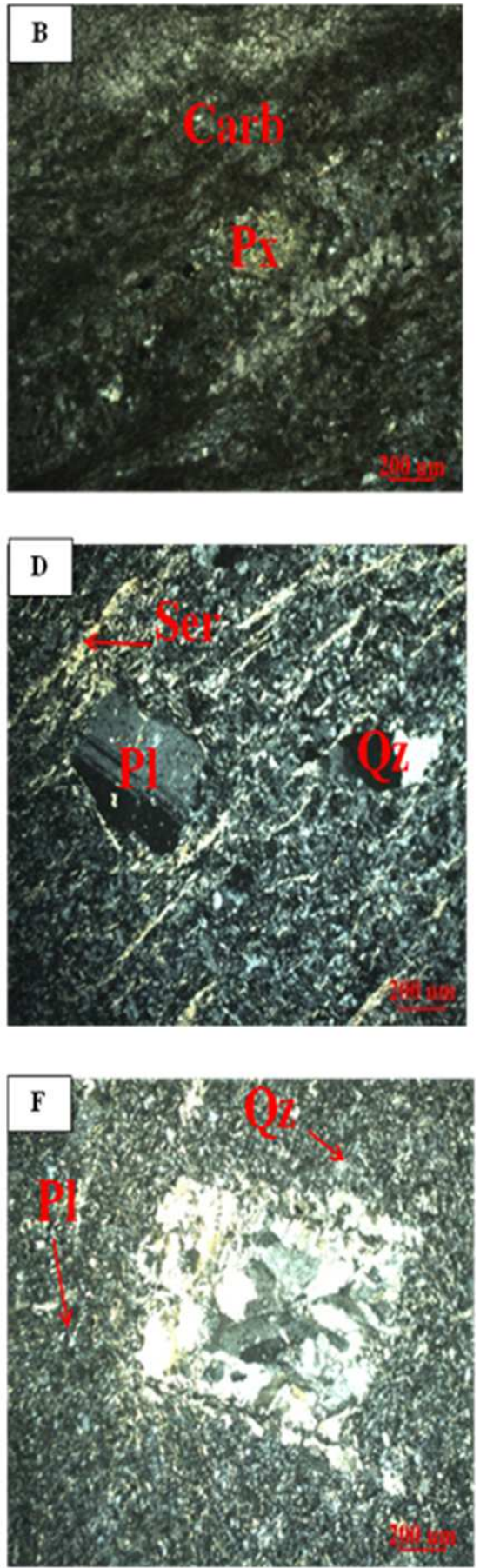

Figure 4. Macroscopic and microscopic aspects of the SAV'OR mine volcanites. A-B: Metabasalt; C-D: Rhyodacite; E-F: Felsic volcaniclastics. Carb: Carbonates; Px: Pyroxene; Ser: Sericite; Pl: Plagioclase; Qz: Quartz.

\subsubsection{Mafic Volcaniclastics}

These rocks are mainly represented by the lappilis tuffs. These basic tuffs are made of pyroxene and amphibole phenocrystals. In the vicinity of the study area, these tuffs are in contact with metasediments (Figure 5 A). Microscopically, these rocks show a porphyritic microlitic texture with pyroxene and green hornblende phenocrystals. The majority of the pyroxene crystals have destabilized into amphibole (Figure $5 \mathrm{~B}$ ). These green hornblende and pyroxene minerals are often altered and transformed into chlorite and epidote. Mesostasis consists of very fine Euhedral lath-shaped plagioclase crystals more or less destabilized into sericite and epidote associated with chlorite. Ferrotitanium oxides are also visibles.

\subsection{Hypovolcanic Rocks}

hypovolcanic rocks are represented by microgranites and aplites. 


\subsubsection{Microgranites}

These rocks with leucocratic color consist of quartz, feldspar, muscovite and biotite (Figure 5 C). Quartz-feldspars veinlets can also be observed with the naked eye. Under the microscope, these rocks show a porphyritic microgranular texture (Figure 5 D). Plagioclase occurs in phenocrystals often altered to sericite and epidote. Quartz often occurs in phenocrystals with remarkable rolling extinction. Mesostasis consists of quartz, alkaline feldspar and plagioclase alkaline plagioclase. In addition, some others minerals like biotites which are usually biotite crystals, usually altered and transformed into chlorite and epidote. Feldspars are altered
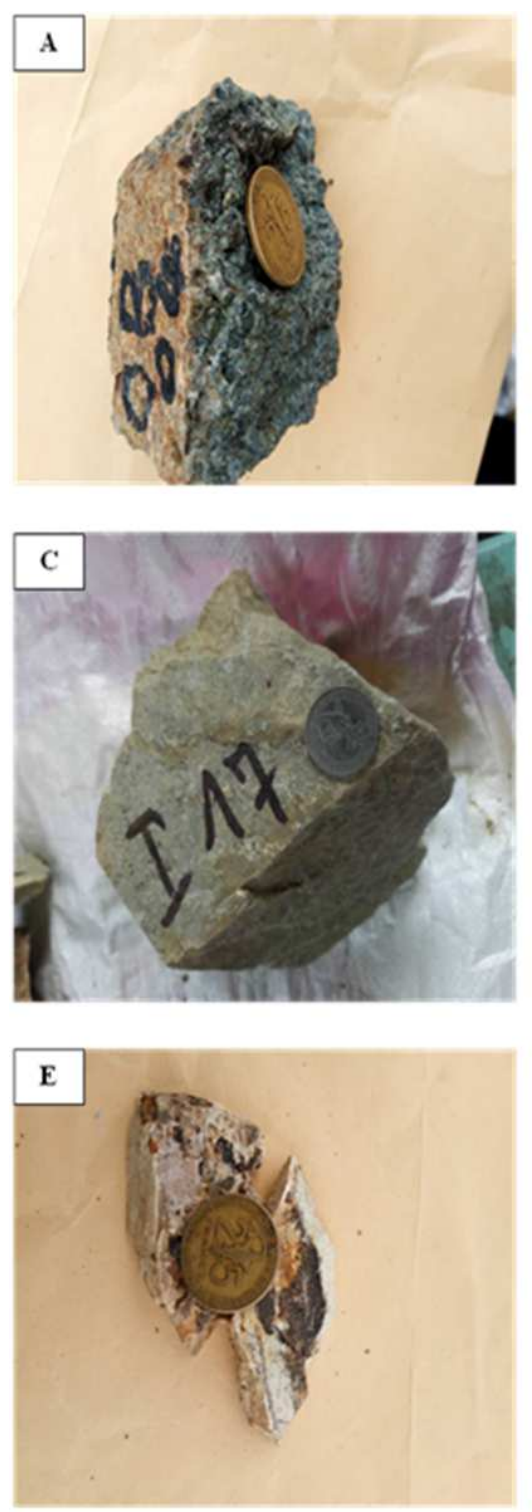

Figure 5. Macroscopic and microscopic aspects of the lappilis tuffs, microgranites, and aplites of the SAV'OR mine. A-B: Lappilis tuffs; C-D: Microgranite; E-F: Aplite. Amp: Amphibole; Ep: Epidote; Ms: Muscovite; Hb. V: Green Hornblende; Fk: Alkaline Feldspars; Chl: Chlorite

\subsection{Plutonic Rocks}

Plutonic rocks observed in the semi-industrial SAV'OR mine at Groudji are represented by metagranodiorites and granodiorites.
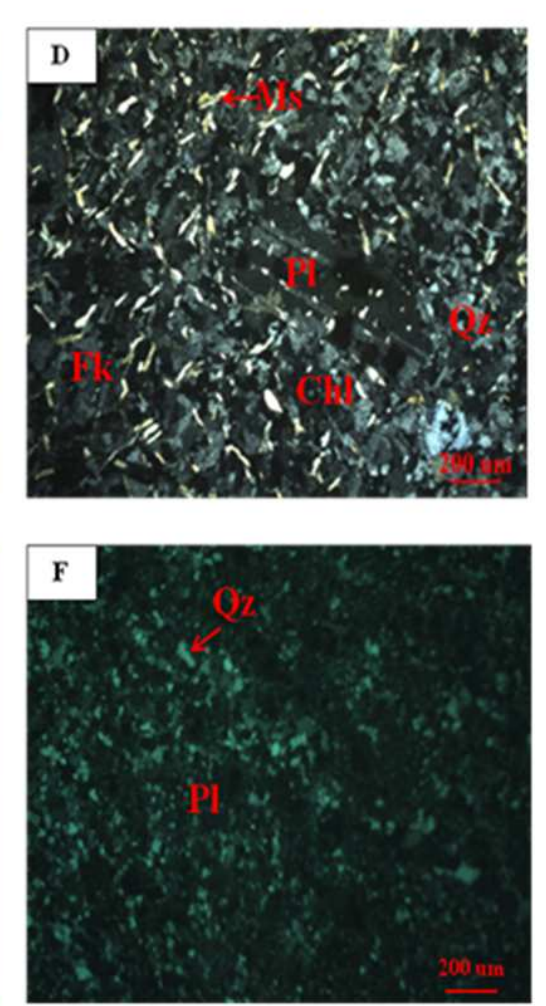

and often transformed into epidote and sericite. Muscovite is also observed. Deformed quartz veinlets as well as quartzfeldspars veinlets associated with chlorite and sericite are observed. Small amount of oxides and sulphides are present.

\subsubsection{Aplites}

Aplites were observed in the study area (Figure 5 E). Near the study area, these veins cross-cutting other rocks in the $\mathrm{N} 100^{\circ}$ direction. In thin section, the rock consists of quartz with a remarkable rolling extinction (Figure $5 \mathrm{~F}$ ). In addition, there are feldspars crystals totally altered and transformed into carbonates (calcite \pm dolomite) and apatite. It is crossed by quartz veinlets. Opaque minerals are also present.

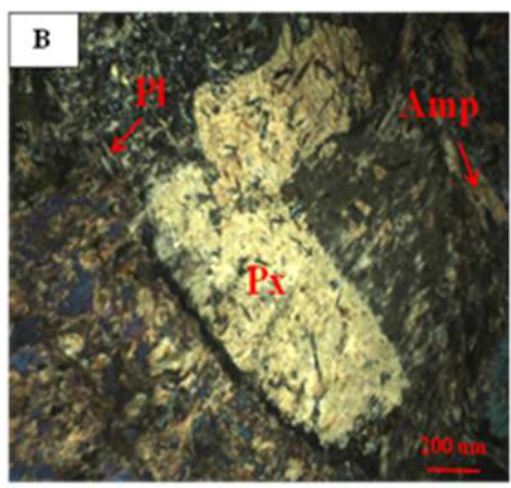


identifiable. Under the microscope (Figure $6 \mathrm{~B}$ ), these rocks show a porphyroid grained texture. The phenocrystals observed are green hornblende, plagioclase and quartz. The quartz shows a remarkable rolling extinction, with crystals of variable size. The green hornblende is altered in some chlorite sections. Plagioclase crystals are often altered to sericite and epidote. Muscovite is also observed. Biotite crystals are present, sub-euhedral with zircon inclusions. The latter are altered and often transform into chlorite and muscovite. Sphene crystals are visibles. Sulphides, mainly represented by pyrite and ferrotitanium oxides are also present.

\subsubsection{Granodiorites}

These rocks with mesocratic color consist of and consist of amphibole, biotite, feldspars and quartz are well identifiables. (Figure $6 \mathrm{C}$ ). Microscopically, these rocks show a grained porphyroid texture with green hornblende, plagioclase and quartz phenocrystals (Figure 6 D). In addition, biotite crystals of medium grain size, muscovite and microcline are present. Plagioclase crystals show magmatic zonation on some sections and are often altered and transformed into sericite and epidote. Ferromagnesians are destabilized into chlorite and epidote. Sphene crystals are visibles. Sulphides represented mainly by pyrite and ferrotitanium oxides are
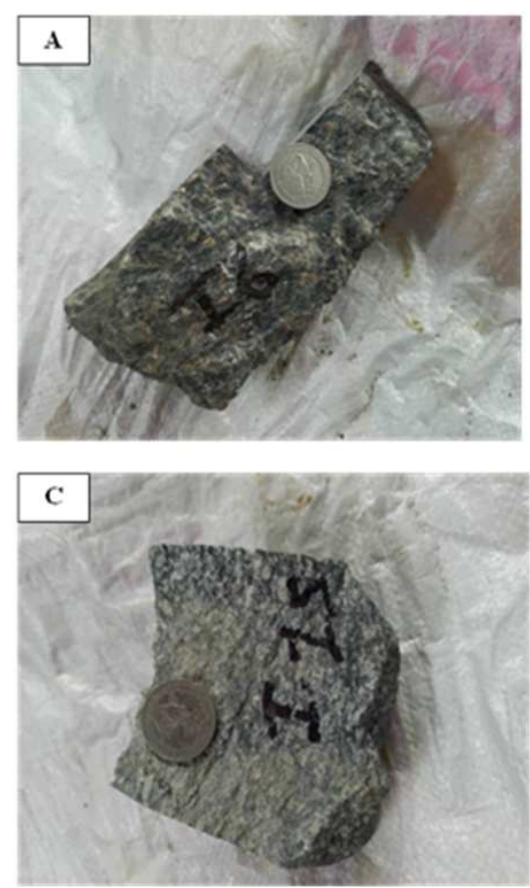

also observed.

\subsection{Metamorphic Rocks}

The metamorphic rocks observed in the semi-industrial SAV'OR mine at Groudji consist mainly of gneiss. These orthogneiss are medium to coarse-grained and show millimetric to centimetric foliation (Figure $6 \mathrm{C}$ ). Microscopically, the rock has a granoblastic texture consisting of quartz, the size of the average grain of the rock (Figure 6 D). Plagioclase often occurs over a wide range, with some sections showing destabilization in carbonates (calcite \pm dolomite), epidote and sericite. The biotite is subeuhedral with zircon inclusions and is mostly altered and transformed into chlorite and epidote. In addition, green hornblende is also present. Sphene and rare opaque minerals as well as ferrotitanium oxides are also observed.

\subsection{Metasediments}

The metasediments generally observed in the study area are chlorite-sericite-schists (Figure $7 \mathrm{C}$ ). These rocks contain a significant amount of sericite and chlorite, which gives them a color ranging from yellowish green to greenish grey. They are in fact schists whose protolith is probably a mafic to intermediate volcanic rocks (basalt or andesite).
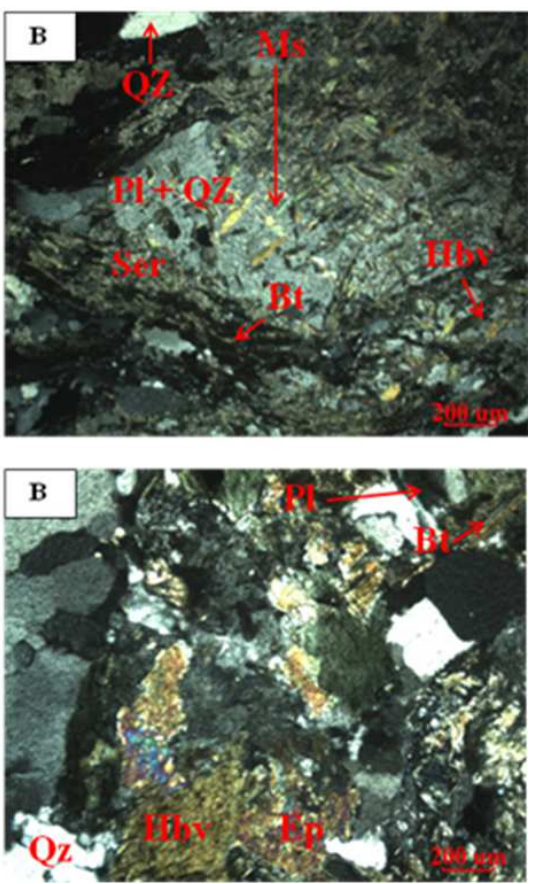

Figure 6. Macroscopic and microscopic aspects of the granitoids of the SAV'OR mine. A-B: Metagranodiorite; C-D: Granodiorite. Hbv: Green Hornblende.

\section{Discussion}

The petrographic study of the semi-industrial SAV'OR mine in Groudji shows a lithological diversity. The lithologies encountered consist of metavolcanic rocks including volcanic lavas (basalts, rhyodacites) and volcaniclastics (mafic tuffs and felsic volcaniclastics). Plutonic rocks are represented by metagranodiorites and granodiorites. In addition to this, there are rocks veins represented by microgranites and aplites. Metamorphic rocks are mainly represented by orthogneiss. The metasediments correspond to chlorite-sericite-schists. All of these lithologies are generally affected by schistosity. According to [11], the geology of the Djékanou department is composed of chloriteschists, ampelites, metavolcanic rocks with brecciated facies, biotite granitic orthogneiss, biotite and/or hornblende granodiorite, and biotite and/or hornblende 
metagranodiorites. Our work in the Groudji zone corroborates more or lees the observations of [11] in the Djékanou department. Indeed, our work has highlighted granodioritic gneisses, microgranites and aplites. The petrographic analysis shows that most of the granitoids are very poor in potassium feldspar, which could indicate that they were put in place during deformation rocks. The presence of volcanic lavas in the study area is related to birimian volcanism. The presence of volcaniclastics indicates an explosive episode. This explosive character has already been demonstrated in the Birimian terrains of Côte d'Ivoire $([8,14,16,23,31])$. These lithologies have generally been affected by phenomena of alteration and/or metamorphism. The primary minerals in these rocks are often altered and transformed into carbonates, sericite, epidote, chlorite, and muscovite. The presence of secondary minerals such as chlorite, epidote, sericite show that these lithologies have been affected by metamorphism of greenschist facies. This corroborates the observations of [23] in the Bonikro deposit.
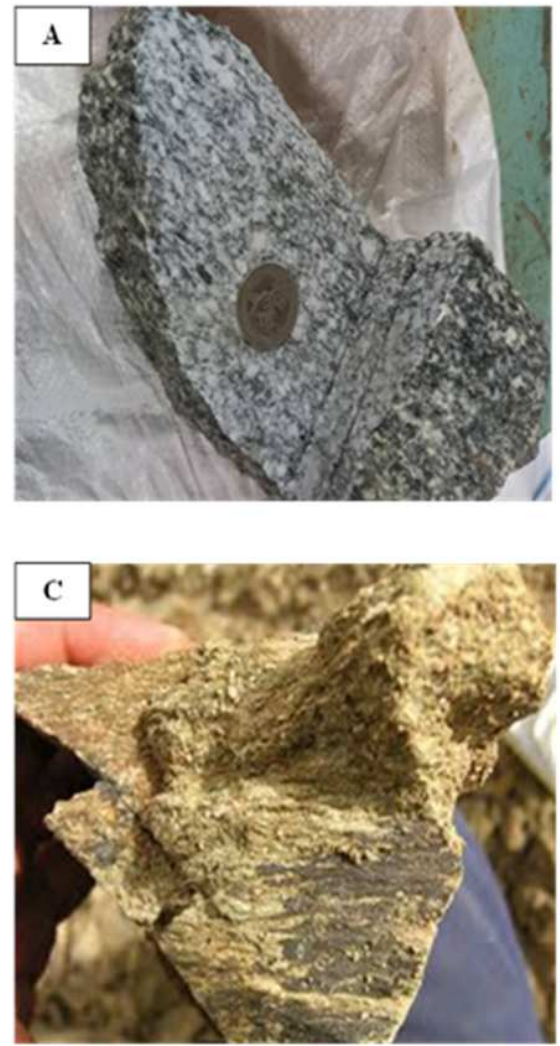

However, some authors such as [29, 30], [16], and [8] highlight in the Birimian terrains, locally, a metamorphism of amphibolite facies, in addition to greenschist facies. All lithologies were affected by hydrothermal alteration marked by quartz, feldspars, and carbonates veins and veinlets, often associated with sericite, chlorite and sulphides. Gold is not visible to the eye in the observed lithologies. This corroborates the observations of [10] in the Bobosso prospect. In fact, these authors found significant hydrothermal alteration in this prospect marked by veins and veinlets of quartz, calcite, \pm tourmaline, \pm sulphides. Gold is not visible to the naked eye even in the highest grade drill sections. However, at Groudji, tourmaline is absent. At Groudji, the mineralized zones are localized zones rich in quartz veins and veinlets; enrichment due mainly to shear zones. This type of mineralization has already been reported in most of the Birimien deposits of Côte d'Ivoire (Aféma: [3, 17]; Angovia: [9]; Bonikro: [13, 23]) and West Africa ([19, 20]).

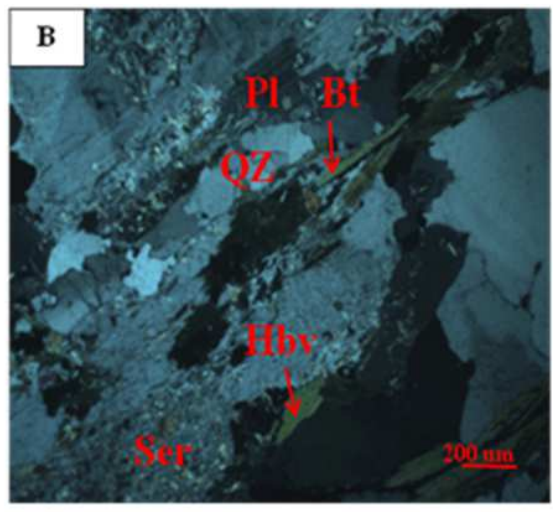

Figure 7. Macroscopic and microscopic aspects of the gneiss and metasediments of the SAV'OR mine. A-B: Gneiss; C: Schist.

\section{Conclusion}

The department of Djékanou is at the heart of the Ivorian Birimian lands in Côte d'Ivoire. Our investigations on the SAV'OR mine highlighted different lithologies. Metavolcanic rocks are composed of volcanic lava (basalt, rhyodacites) and felsic and mafic volcaniclastics. In addition, there are hypovolcanic rocks represented by aplites and microgranites. The plutonic rocks is composed of metagranodiorites and granodiorites. The metasediments are essentially composed of chlorite-sericite-schists. The metamorphic unit consists of gneisses. All lithologies have been affected by hydrothermal alteration marked by quartz, feldspars and carbonates veins and veinlets, often associated with sericite, chlorite and sulphides. Gold is not visible to the eye in the observed lithologies. Metavolcanic rocks indicate that effusive volcanism as well as explosive volcanism prevailed in the study area. Secondary minerals observed are carbonates, sericite, epidote, chlorite, and muscovite. These lithologies were affected by a metamorphism of greenschist facies. 


\section{Acknowledgements}

The authors would like to express their gratitude to the company SAV'OR-CI SARLU for allowing access to their site to carry out the field phase and the collection of samples for laboratory analysis.

\section{References}

[1] Abouchami W. (1990). A major volcanic event around $2.1 \mathrm{Ga}$ in West Africa: An early stage of crustal accretion. University Doctorate, Nancy I.

[2] Abouchami W., Boher M., Michard A., Albarede F. (1990). A Major 2.1Ga Event of Mafic Magmatism in West Africa: An Early Stage of Crustal Accretion. J. Geophys. Res, 95: 1760517629.

[3] Assié K. E. (2008). Lode gold mineralization in the Paleoproterozoic (Birimian) volcanosedimentary sequence of Afema gold district, southeastern Côte d'Ivoire. Thesis, Facult y of Energy and Economic Sciences. Technical Universit y of Clausthal, Germany, 198p.

[4] Baratoux L., Metelka V., Naba S., Jessell M. W., Gregoire M., Ganne J. (2011). Juvenile Paleoproterozoic crust evolution during the Eburnean orogeny $(22.2-2.0 \mathrm{Ga})$, western Burkina Faso. Precambrian Res. 191, 18-45.

[5] Bessoles B. (1977). Geology of Africa. Flight 1: the West African Craton. Bur. Rech. Geol. Min. Same. 88. 402 P.

[6] Boher M., Abouchami W., Michard A., Alberede F., Arndt N. (1992). Growth of the Earth's crust in West Africa at 2.1 Ga. Journal Geophysical Research. 97, 345-369.

[7] Chermette A. (1935). The gold-bearing quartz veins of Hiré (Ivory Coast). Report $\mathrm{n}^{\circ}$ 200, Gouv. gen. of the A. O. F., Insp. gen. des P. T., Serv. des Mines, Dakar, September 1935.

[8] Coulibaly I. (2018). Petrography of volcanics and plutonites of the southern part of the volcanosedimentary groove of Toumodi-Fétèkro. Thesis Univ. Félix Houphouët-Boigny d'Abidjan, 218p.

[9] Coulibaly Y., Boiron M. C., Cathelineau M., And Kouamelan A. N. (2008). Fluid immiscibility and gold deposition in the Birimian quartz veins of the Angovia deposit (Yaouré, Côte d'Ivoire). Journal of African Earth Sciences 50, pp. 234-254.

[10] Coulibaly Y., Kouaho, B., Gnanzou, A., Allialy, ME \& Djro, SC (2012). Geological context of the gold mineralization of the Bobosso prospect (Dabakala region, north-central Côte d 'Ivory). J. Rech. Sci. Univ. Lomé (Togo), 2012, Serie A, 14 (2): 149-162.

[11] Daouda YB, Delor C., Simeon Y., Diaby I., Gadou G., Kohou P., Okou A., Konate S., Konan G., Vidal M., Cocherie A., Dommaget A., Cautru JP Et Chiron J. C. (1995). Geological map of the Côte d'Ivoire at $1 / 200000$, sheet by Dimbokro, Ministry of Mines and Energy, Directorate of Geology, Abidjan, Côte d'Ivoire.

[12] Doumbia S., Pouclet A., Kouamelan A., Peucat J. J., Vidal M. (1998). Petrogenesis of juvenile-type Birimian (Paleoproterozoic) granitoïds in Central Côte d'Ivoire, West Africa: geochemistry and geochronology. Precambrian
Research 87, 33-63.

[13] Gnanzou A. (2006). Lithostratigraphic study of the region of Hiré in the center-south of the Côte d'Ivoire (Research permit PRA 37): Involvement in the knowledge of gold mineralization. DEA, UFR-STRM, Univ. Cocody, 60 p.

[14] Gnanzou A. (2014). Study of the volcano-sedimentary series of the Dabakala region (North-East of the Côte d'Ivoire): genesis and magmatic evolution. Contribution to the knowledge of the gold mineralization of Bobosso in the Haute-Comoé series. Doctoral thesis, Univ. Paris-Sud Orsay, France and Univ. Félix Houphouët-Boigny, 303p.

[15] Hirdes W., Davis D. W., Ludtke G., Konan G. (1996). Two generations of Birimian (Paleoproterozoic) volcanics belts in northeastern Côte d'Ivoire (West-Africa): consequences for the 'Birimian Controversy'. 247-311.

[16] Houssou N. N. (2013). Petrological, structural and metallogenic study of the Agbahou gold deposit, Divo, Côte d'Ivoire. Doctorate, Univ. Félix Houphouët -Boigny, 177p.

[17] Kadio, E., Coulibaly, Y., Allialy, M. E., Kouamelan, A. N., Pothin, K. B. K. (2010). On the occurrence of gold mineralizations in southeastern Côte d'Ivoire. Journal of African Earth Sciences 57, 423-430.

[18] Kramo K. B., Coulibaly Y., Pothin K. B. K. and Kadio E. (2008). Mineralogical and Chemical Characters of the Aféma Shear Zone Gold Mineralization, South-East of Côte d'Ivoire: Example of the Hermann Mine. European Journal of Scientific Research, 21, n 1 , pp. 154-163.

[19] Milési JP, Feybesse JL, Ledru P., Dommanget A., Ouédraogo MF, Marcoux E., Prost AE, Vinchon C., Sylvain JP, Johan V., Tegyey M., Calvez JY, Lagny Ph. (1989). Gold mineralization of West Africa. Their lithostructural evolution in the Lower Proterozoic. Chron. Rech. min., Fr., 497: 3-98.

[20] Milesi J. P., Ledru P., Feybesse J. L., Dommanget A. and Marcoux E. (1992). Early Proterozoïc ore deposits and tectonics of the Birimian orogenic belt, West Africa. Precambrian Research 58, I ssues 1-4, pp. 305-344.

[21] Milesi J. P., Feybesse J. L., Pinna P., Deschamps Y., Kampunzu H., Muhongo S., Lescuyer J. L., Le Goff E., Delor C. and Billa M. (2004). Geological map of Africa 1:10,000,000. SIG Afrique project, BRGM Orléans.

[22] Ouattara S. (2018). The Dougbafla-Bandama deposit (South of the Birimian furrow of Fêttêkro, Oumé, Côte d'Ivoire): Petrography, deformation, geochemistry and metallogeny. Doctorate, Univ. FELIX HOUPHOUET-BOIGNY, 252 p.

[23] Ouattara Z. (2015). Lithostratigraphic, structural, geochemical and metallogenic characters of the Bonikro gold deposit, Fettekro Bireimian Trench, south-central Côte d'Ivoire. Ph.D., Univ. FELIX HOUPHOUET-BOIGNY, 256 p.

[24] Pawlig S., Gueye M., Klischies R., Schwarz S., Wemmer K., Siegesmund S. (2006). Geochemical and $\mathrm{Sr}-\mathrm{Nd}$ isotopic data on the Birimian of the Kedougou-Kenieba Inlier (Eastern Senegal): implications on the Palaeoproterozoic evolution of the West African Craton. S. Afr. J. Geol. 109, 411-427.

[25] Peucat J. J., Capdevila R., Drareni A., Mahdjoub Y., Kahoui M. (2005). The Eglab massif in the West African Craton (Algeria), an original segment of the Eburnean orogenic belt: petrology, geochemistry and geochronology. Precambr. Res. 136, 309-352. 
[26] Tagini B. (1972). Geological map of Côte d'Ivoire at a scale of 1:2,000,000. SODEMI-ORSTOM-University of Abidjan.

[27] Taylor P. N., Moorbath S., Leube A., Hirdes W. (1988). Geochronology and crustal evolution of Early Proterozoic granite-greenstone terrains in Ghana/ West Africa (abs.), in International conference on the geology of Ghana with special emphasis on gold: Accra, Geol. Surv. Ghana 75th Anniv. Pub., 43-45.

[28] Taylor P. N., MoorbathS., Leube A., Hirdes W. (1992). Early Proterozoic crustal evolution in the Birimian of Ghana: constraints from geochronology and isotope geochemistry. Precambrian Res., 56: 97-111.
[29] Yacé I. (1976). Eburnean volcanism in the central and southern parts of the Precambrian range of Fettekro in Côte d'Ivoire. State doctorate thesis. Univ Abidjan. 373 p.

[30] Yacé I. (1982). Study of Eburnean volcanism in the central and southern parts of the Precambrian chain of Fettekro. Directorate of Geology. Abidjan. $156 \mathrm{p}$.

[31] Yao K K. A. (1993). The volcanism of the Boundiali furrow, the main phenomenon of the Lower Paleoproterozoic of this N. NW region of the Côte d'Ivoire. Petrology, geochemistry, geochronology. Thesis, Univ. Clermot-Ferrand 2, 218 p. 